\title{
Hepatoerythropoietic porphyria precipitated by viral hepatitis
}

\author{
R J Hift, P N Meissner, G Todd
}

\begin{abstract}
Porphyria cutanea tarda (PCT), the condition resulting from a deficiency of hepatic uroporphyrinogen decarboxylase activity, is the commonest form of porphyria. Both acquired and familial form exist and are commonly associated in adults with liver disease and hepatic iron overload. The condition is extremely rare in children; most cases of childhood PCT are familial and some particularly severe cases have been shown to have a hepatoerythropoietic porphyria or homozygous uroporphyrinogen decarboxylase deficiency. A case is described of hepatoerythropoietic porphyria in which the disease was first precipitated at the age of two by a coincidental hepatitis $A$ infection and improved as the hepatitis cleared. This paper reviews the evidence that viral hepatitis may precipitate overt PCT in children in a manner analagous to the precipitation of PCT in adults by alcohol associated liver disease.

(Gut 1993; 34: 1632-1634)
\end{abstract}

Porphyria cutanea tarda (PCT) is characterised biochemically by the increased urinary excretion of the water soluble porphyrin intermediates uroporphyrin, hepta, hexa, and pentacarboxylic porphyrin, and the accumulation of porphyrins in the plasma and liver. It occurs as a result of a defect of the haem synthetic enzyme uroporphyrinogen decarboxylase. Whereas all other forms of porphyria are inherited as classic Mendelian traits, PCT is usually an acquired illness, which typically develops in adult life. Characteristically the condition occurs in association with liver disease (usually secondary to alcohol) and is associated with hepatic iron overload. Other rarer associations include exposure to polyhalogenated hydrocarbons, oestrogen treatment, lymphoma, carcinoma, systemic lupus erythematosus, and chronic renal failure treated by haemodialysis. The principal symptom is photosensitivity, resulting in blistering, scarring, milia, pigmentation, and hirsutes in sun exposed areas. Occasionally the damage is severe enough to mimic scleroderma.

A familial form, inherited as a Mendelian dominant trait, is well described. Though the clinical features are the same, the familial form may be distinguished from the acquired form by the presence of a family history and by the finding of reduced uroporphyrinogen decarboxylase activity in erythrocytes as well as hepatocytes. The familial form, interestingly, also becomes clinically manifest in later adult life and the same association of liver disease and iron overload is often noted.

PCT is rarely manifest in infancy or childhood, and with the exception of an outbreak in Turkey, where large numbers of children developed PCT after ingesting wheat contaminated with hexachlorobenzene, ${ }^{2}$ few cases of infantile PCT have been described. ${ }^{3-17}$

A subgroup of affected children have a form of PCT characterised by severe photosensitivity starting in early childhood, considerably raised porphyrins, and a characteristic raised erythrocyte protoporphyrin. ${ }^{18-22}$ These changes are often severe enough to mimic congenital erythropoietic porphyria. This condition has been shown to represent the homozygous form of familial PCT, with uroporphyrinogen decarboxylase activities typically being less than $10 \%$ of the control range ${ }^{23}$ and has been labelled hepatoerythropoietic porphyria. The underlying genetic defect has now been determined in some patients. ${ }^{24-25}$ Both homozygous and compound heterozygous mutations have been identified.

We describe here a two year old child in whom severe PCT was apparently precipitated by hepatitis A. Biochemical characterisation of the enzyme defect suggests the presence of hepatoerythropoietic porphyria, the severity of the PCT declined as the hepatitis improved.

\section{Case report}

A two year old black child presented to a paediatric hospital. The child had passed red urine and had developed a skin eruption over the preceding month. Both parents were healthy, and the child had had no previous medical or dermatological problems. There was no history of exposure to medicines, chemicals, or pesticides. The parents were not consanguineous.

The child was well nourished; height and weight fell on the 50th percentile. Hypo and hyperpigmented patches on the nose and cheeks were noted. Erosions, scabs, and pigmentary changes were noted on her hands, cheeks, and forehead. Her hands and fingers were foreshortened. The nails showed onycholysis. She was mildly jaundiced. Her liver was slightly enlarged but not tender. No splenomomegaly was noted and there were no signs of hepatic decompensation.

Serum chemistry suggested hepatitis (Table I). A full blood count was normal. IgM antibodies to hepatitis $A$ virus were found, confirming an acute hepatitis A infection. Iron studies and serum ferritin showed no evidence of iron overload. Urine, stool, plasma, and erythrocyte porphyrins were esterified and extracted into chloroform, separated by thin layer chromatography and assessed by fluoroscanning, using a commercial standard kit (Porphyrin Products, Logan, Utah) as the standard. ${ }^{26-27}$ Table II shows the urinary porphyrin concentrations, which were among 
TABLE I Tests of liver function and iron storage in the patient

\begin{tabular}{lcl}
\hline & & $\begin{array}{l}\text { Reference } \\
\text { range }\end{array}$ \\
\hline Total protein & $80 \mathrm{~g} / 1$ & $(60-80)$ \\
Albumin & $29 \mathrm{~g} / \mathrm{l}$ & $(35-55)$ \\
Total bilirubin & $39 \mathrm{umol} / 1$ & $(1-17)$ \\
Conjugated bilirubin & $26 \mathrm{umol} / 1$ & $(1-17)$ \\
Aspartate aminotransferase & $454 \mathrm{IU} / 1$ & $(7-25)$ \\
Alanine aminotransferase & $501 \mathrm{IU} / 1$ & $(1-25)$ \\
$\gamma$ glutamyl transpeptidase & $85 \mathrm{IU} / 1$ & $(0-50)$ \\
Serum iron & $17 \mathrm{umol} / 1$ & $(8-30)$ \\
Total iron binding capacity & $45 \mathrm{umol} / 1$ & $(48-67)$ \\
Transferrin saturation & $38 \%$ & $(18-52)$ \\
Ferritin & $166 \mathrm{ng} / \mathrm{ml}$ & $(20-300)$ \\
\hline
\end{tabular}

the highest ever encountered in our laboratory. These, together with stool and plasma porphyrins, were diagnostic of PCT.

Repeated porphyrin measurement in the urine, stool, red cells, and plasma of the mother showed no abnormality. The father, however, who was clinically normal, showed biochemical evidence of PCT. Normal iron studies and serum ferritin excluded iron overload in his case, though a liver biopsy showed moderate amounts of haemosiderin as the only abnormality.

An erythrocyte uroporphyrinogen decarboxylase activity assay, determined by measuring the production of coproporphyrinogen from pentacarboxyl-porphyrinogen III in haemolysates of anticoagulated whole blood samples, showed a reduction to $20 \%$ of expected activity in the patient, to $60 \%$ in the father, and to $50 \%$ in the mother (Table II). The concentration of immunoreactive uroporphyrinogen decarboxylase was determined by electroimmunoassay in agarose gels using a rabbit antiserum to human erythrocyte uroporphyrinogen decarboxylase

TABLE II Porphyrin and enzyme values

\begin{tabular}{|c|c|c|c|c|}
\hline & Patient & Father & Mother & $\begin{array}{l}\text { Reference } \\
\text { range }\end{array}$ \\
\hline $\begin{array}{l}\text { Urine porphyrins } \\
\text { (nmol/10 mmol cr } \\
\text { Uroporphyrin } \\
\text { 7-COOH } \\
\text { 6-COOH } \\
\text { 5-COOH } \\
\text { Copro }\end{array}$ & $\begin{array}{r}77954 \cdot 2 \\
29734 \cdot 7 \\
6136 \cdot 1 \\
5380 \cdot 6 \\
709 \cdot 7\end{array}$ & $\begin{array}{r}404 \cdot 8 \\
102 \cdot 9 \\
125 \cdot 0 \\
35 \cdot 6 \\
97 \cdot 1\end{array}$ & $\begin{array}{r}3 \cdot 2 \\
1 \cdot 2 \\
0 \cdot 0 \\
0 \cdot 0 \\
36 \cdot 1\end{array}$ & $\begin{array}{l}<20 \\
<1 \cdot 5 \\
\mathrm{UD} \\
\mathrm{UD} \\
<240\end{array}$ \\
\hline $\begin{array}{l}\text { Stool porphyrins } \\
\text { (nmol/g dry weigh } \\
\text { Uroporphyrin } \\
\text { 7-COOH } \\
\text { 6-COOH } \\
\text { 5-COOH } \\
\text { Isocopro } \\
\text { Copro } \\
\text { Proto }\end{array}$ & $\begin{array}{r}5 \cdot 5 \\
4 \cdot 4 \\
1 \cdot 7 \\
5 \cdot 6 \\
8 \cdot 8 \\
4 \cdot 9 \\
29 \cdot 6\end{array}$ & $\begin{array}{r}1 \cdot 2 \\
7 \cdot 3 \\
1 \cdot 3 \\
12 \cdot 0 \\
24 \cdot 6 \\
14 \cdot 9 \\
130 \cdot 3\end{array}$ & $\begin{array}{r}0 \cdot 8 \\
0 \cdot 0 \\
0 \cdot 0 \\
0 \cdot 0 \\
0 \cdot 0 \\
16 \cdot 9 \\
90 \cdot 3\end{array}$ & $\begin{array}{l}<1 \cdot 7 \\
\text { UD } \\
\text { UD } \\
\text { UD } \\
\text { UD } \\
<50 \\
<200\end{array}$ \\
\hline $\begin{array}{l}\text { Erythrocyte porphy } \\
\text { (nmol/l) } \\
\text { Copro } \\
\text { Proto }\end{array}$ & $\begin{array}{l}0 \cdot 0 \\
1792\end{array}$ & $\begin{array}{r}0.0 \\
683.9\end{array}$ & $\begin{array}{r}0 \cdot 0 \\
776.9\end{array}$ & $\begin{array}{l}<80 \\
<800\end{array}$ \\
\hline 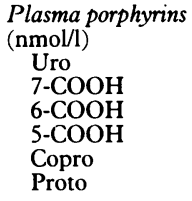 & $\begin{array}{r}12 \cdot 1 \\
6 \cdot 6 \\
6 \cdot 0 \\
7 \cdot 1 \\
0 \cdot 0 \\
3 \cdot 0\end{array}$ & $\begin{array}{l}5 \cdot 9 \\
2 \cdot 9 \\
1.6 \\
0 \cdot 0 \\
3 \cdot 0 \\
0 \cdot 0\end{array}$ & $\begin{array}{l}\text { UD } \\
\text { UD } \\
\text { UD } \\
\text { UD } \\
\text { UD } \\
\text { UD }\end{array}$ & $\begin{array}{l}<2 \cdot 5 \\
\text { UD } \\
\text { UD } \\
\text { UD } \\
\text { UD } \\
<1 \cdot 0\end{array}$ \\
\hline $\begin{array}{l}\text { Uroporphyrinogen } \\
(\mathrm{pmol} / \mathrm{min} / \mathrm{mg} \text { hae }\end{array}$ & $\begin{array}{l}\text { e activity } \\
\qquad 1.03\end{array}$ & $2 \cdot 80$ & $2 \cdot 52$ & $3 \cdot 85-6 \cdot 20$ \\
\hline $\begin{array}{l}\text { Immunoreactive ur } \\
\text { (arbitrary units) }\end{array}$ & $\begin{array}{c}\text { en decarbox } \\
\quad<20\end{array}$ & 60 & 54 & $64-103$ \\
\hline
\end{tabular}

$\mathrm{UD}=$ undetectable and purified human erythrocyte uroporphyrinogen decarboxylase as the standard. ${ }^{28}$ This showed a reduction to less than $20 \%$ in the patients, to $60 \%$ in the father, and $54 \%$ in the mother. Both assays were kindly performed by Professor G Elder, University of Wales College of Medicine.

No specific treatment other than topical sun blockers and advice about sun protection were given. The biochemical evidence of hepatitis resolved completely over two months, and disappearance of the anti-HAV IgM antibody was seen. Porphyrin excretion concentrations fell dramatically over the ensuing months in parallel with the improvement in liver function and the skin disease became less active. At six months, the total urinary porphyrins had declined from $119914 \mathrm{nmol} / 1$ to $1210 \mathrm{nmol} / \mathrm{l}$ and plasma porphyrins from 35 to $18 \mathrm{nmol} / \mathrm{l}$. We lost contact with the family thereafter.

\section{Discussion}

That uroporphyrinogen decarboxylase activity and immunogenic uroporphyrinogen decarboxylase material are decreased proportionately to about half of control values is compatible with a cross reacting immunomaterial negative uroporphyrinogen decarboxylase mutation in both parents, resulting in biochemically expressed though asymptomatic familial PCT in the father and a silent carrier state in the mother. The more severe deficiency in the child is highly suggestive of the presence of homozygous or compound heterozygous familial PCT, in other words, hepatoerythropoietic porphyria. This may account for the early onset, severity, and unusual biochemical findings such as the raised erythrocyte protoporphyrin.

Symptomatic PCT was apparently precipitated at an unusually young age in our patient by an intercurrent acute hepatitis A infection, a conclusion which is supported by its improvement as the hepatitis resolved. Though an association between PCT and viral hepatitis is recognised by some authorities (G Elder, personal communication), this is rarely reported, particularly in English publications. In children, precipitation of PCT by exogenous factors is occasionally described. PCT followed the administration of drugs (sulphonamides and griseofulvin, and hydantoin and benzodiazepines respectively) in two children who were shown to have the familial form of the disease. ${ }^{9}$ Dopfer described a 6 year old girl who developed PCT after bone marrow transplantation for chronic myeloid leukaemia. ${ }^{6}$ Though her transaminase activities were abnormal, she did not have clinical hepatitis or evidence of viral infection and the liver disturbance was felt to be secondary to methotrexate use. Prolonged administration of parenteral or enteral iron may have resulted in PCT in a susceptible child aged $8 .{ }^{17}$

With the exception of a recent surge of reports of adult onset PCT in association with HIV infection, ${ }^{29-30}$ the association of PCT and viral infection is rare. Taylor ${ }^{16}$ described the apparent precipitation of PCT in an 11 year old boy who developed infectious mononucleosis. French publications include a few reports on an associa- 
tion between PCT and viral hepatitis. PCT was felt to have been precipitated by viral hepatitis in a 4 year old girl ${ }^{4}$ and in a 5 year old child with trisomy 22 who had an intercurrent hepatitis $A .^{12}$ The possible role of hepatitis $B$ surface antigenaemia in a case of PCT was discussed by Arlet $^{31}$ and an association between PCT and viral hepatitis in a child was postulated by Gajdos. ${ }^{8}$

Even with adult onset familial PCT, there is often a history of exposure to alcohol or other precipitating factors, suggesting that a liver specific process may also determine the onset of overt PCT. ${ }^{32}$ Thus even the familial form may only become manifest where the uroporphyrinogen decarboxylase mutation underlying the condition is accompanied by a hepatic insult, such as alcohol, which leads by unknown mechanisms to the inactivation of uroporphyrinogen decarboxylase in sufficient degree to interfere with porphyrin metabolism. Our experience would suggest that viral hepatitis represents one such insult that might precipitate PCT in the genetically predisposed subject. Because the association has been rarely reported, the association would seem to be uncommon; it is however possible that overt PCT or hepatoerythropoietic prophyria is preceded by viral hepatitis more frequently than is recognised, as many infections, particularly in children, are subclinical or trivial.

We thank Professor F Bonnici for allowing us to study this patient, Mr B Davison and Ms J Sutherland for performing the porphyrin quantitations, and Ms L Petersen for her expert assistance with the preparation of the manuscript.

1 Kushner JP, Barbuto AJ, Lee JR. An inherited enzymatic defect in porphyria cutanea tarda. Decreased defect in porphyria cutanea tarda. Decreased uroporphyrinogen

2 Gocmen A, Peters HA, Cripps DJ, Bryan GT, Morris CR. Hexachlorobenzene episode in Turkey. Biomed Environment Sciences 1989; 2: 36-43.

3 Battle AM, Del C, Stella AM, De Kaminsky AR, Kaminsky C, Mariano HG. Two cases of infantile porphyria cutanea tarda: Successful treatment with oral $S$-adenosyl-L-methionine and low-dose oral chloroquine. $B r \mathcal{F}$ Dermatol 1987; 116: 407-15.

4 Cotton JB, Abeille A, Jeune R, Ladreyt-Ponchon J-P, Grenier $\mathrm{J}-\mathrm{L}$. Porphyria cutanee tardive chez une enfant de 4 ans avec deficit en uroporphyrinogene decarboxylase. Pediatrie 1986; 41: 617-27.

5 Day RS, Strauss PC. Severe cutaneous porphyria in a 12-yearold boy. Arch Dermatol 1982; 118: 663-7.

6 Dopfer R, Doss M, Ehninger G, Ostendorf P, Niethammer D. Appearance of an inherited porphyria cutanea tarda in a
child after allogeneic bone marrow transplantation for child after allogeneic bone marrow transplantation for chronic myelo

7 Doutre MS, Beylot C, Bioulac P, Nordmann Y. Porphyrie cutanee dite tardive de l'enfant: A propos d'un cas avec etude enzymatique familiale. Ann Dermatol Venereol 1981; 108: $751-7$

8 Gajdos A, Plainfosse B, Seringe P. Porphyrie cutanée dite de l'adulte chez un enfant révélée par une hépatite virale, traitement par l'acide adénosine 5' monophosphorique. Presse Med 1967; 75: 345-7.

9 Herrero C, Muniesa A-M, Lecha M, Elder GH, Mascaro JM The early forms of porphyria cutanea tarda. Report of two cases with studies of the enzymatic defect in relatives and precision of the genetic inheritance. Ann Dermatol Venereol 1984; 111: 973-8.

10 Kansky A. Porphyria cutanea tarda in a 2-year-old girl. Br F Dermatol 1974; 90: 213-6.

11 Lambert DG, Beer F, Dalac S, Hourdain M-J. Familia porphyria cutanea tarda in a 7-year-old girl. Dermatologica 1988; 176: 202-4.

12 Mariani $R$, De Vereuil $H$, Albertini M, Lambert JM, Kermarec J. Porphyrie cutanée dite tardive chez un tri-

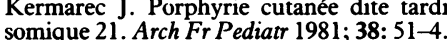

13 Prada MJC, de Salamanca RE, Hernando MV, Payero MLP Beltran TC, Aguilar AR. Two cases of infantile and familia porphyria cutanea tarda. Dermatologica 1980; 161; 205-10.

14 Rogers M,Kamath KR, Poulos V. Porphyria cutanea tarda in a seven year old child. Aust $\mathcal{F}$ Dermatol 1984; 25: 107-12.

15 Tamayo L, Ruiz-Maldonado R, Ridaura C. Porphyria cutanea tarda symptomatica in children treated with chloroquine. Report of four cases with control liver biopsies. $\mathcal{F}$ Dermato 1985; 12: 329-40.

16 Taylor GF, Norris GC. An unusual porphyrinuria precipitated by viraemia. Aust $f$ Derm 1984; 25: 113-4.

17 Welland FH, Ray AC. Porphyria cutanea tarda in an 8-year-old boy. Arch Dermatol 1969; 99: 451-4.

18 Smith SG. Hepatoerythropoietic porphyria. Semin Dermatol 1986; 5: 125-37.

19 Bundino S, Topi GC, Zina AM, D'Allesandro Gandolfo L. Hepatoerythropoietic porphyria. Pediatr Dermatol 1987; 4 229-33.

20 Lazaro P, De Salamanca RE, Elder GH, Villaseca ML, Chinarro S, Jaqueti G. Is hepatoerythropoietic porphyria homozygous form of porphyria cutanea tarda? Inheritance of uroporphyrinogen decarboxylase deficiency in a Spanish family. Br ₹ Dermatol 1984; 110: 613-7.

21 Lim HW, Poh-Fitzpatrick MB. Hepatoerythropoietic porphyria: a variant of childhood-onset porphyria cutanea tarda. ₹ Am Acad Dermatol 1984; 11: 1103-11

22 Tobrack AC, Sassa S, Poh-Fitzpatrick M, Schechter J, Zaider E, Harber LC, et al. Hepatoerythropoietic porphyria: clinical, biochemical and enzymatic studies in a three-generation family lineage. N Engl F Med 1987; 316: 645-50.

23 De Verneuil H, Beaumont C, Deybach J-C, Nordmann Y, Sfar Z, Kastally R. Enzymatic and immunological studies of uroporphyrinogen decarboxylase in familial porphyria cutanea tarda and hepatoerythropoietic porphyria. Am $\mathcal{F}$ Hum Genet 1984; 36: 613-22.

24 De Verneuil H, Bourgeois F, De Rooij F, Siersma PD, Wilson $\mathrm{JH}$, Grandchamp B, et al. Characterization of a new mutation (R292G) and a deletion at the human uroporphyrinogen decarboxylase locis in two patients with hepatoerythropoietic porphyria. Hum Genet 1992; 89: 54852 .

25 Romana M, Grandchamp B, Dubart A, Amselem S, Chabret $\mathrm{C}$, Nordmann $\mathrm{Y}$, et al. Identification of a new mutation responsible for hepatoerythropoietic porphyria. Eur $\mathcal{f}$ Clin Invest 1991; 21: 225-9.

26 Day RS, De Salamanca RE, Eales L. Quantitation of red cell porphyrins by fluorescence scanning after thin layer chromatography. Clin Chim Acta 1978; 89: 25-33.

27 Day RS, Pimstone NR, Eales L. The diagnostic value of blood plasma porphyrin methyl ester produced by quantitative TLC. Int $\mathcal{F}$ Biochem 1978; 9: 897-904.

28 Elder GH, Urquhart AJ, De Salamanca RE, Munoz JJ, Bonkovsky HL. Immunoreactive uroporphyrinogen decarboxylase in the liver in porphyria cutanea tarda. L ancet 1985; ii: $229-32$.

29 Blauvelt A, Harris HR, Hogan DJ, Jiminez-Acosta F, Ponce I, Pardo RJ. Porphyria cutanea tarda and human immunodeficiency virus infection. Int f Dermatol 1992; 31: 474-9.

30 Boisseau AM, Couzigou P, Forestier JF, Legrain V, Aubertin J, Doutre MS, et al. Porphyria cutanea tarda associated with J, Doutre MS, et al. Porphyria cutanea tarda associated with human immunodeficiency virus infection. A study of four cases and

31 Arlet P, Vinel JP, Duffaut M, Gaillemin C, Le Tallec Y. Porphyrie cutanée tardive avec recherche positive d'antigène HBs. Nouv Presse Med 1978; 7: 3558.

32 Elder GH, Roberts AG, de Salamanca RE. Genetics and pathogenesis of human uroporphyrinogen decarboxylase defects. Clin Biochem 1989; 22: 163-8. 